\title{
The Assessment of Factors Influencing Hotel Services Consumers Behaviour
}

\author{
Mohamad Alaa Ktait, Far Eastern Federal University, 8 Sukhanova St., Vladivostok, Russia. \\ Elena Borisovna Kmet, Vladivostok State University Economy and Service, 41, Gogolya St., Vladivostok, Russia. \\ Far Eastern Federal University, 8 Sukhanova St., Vladivostok, Russia. \\ Lyudmila Yurevna Dragileva, Vladivostok State University Economy and Service, 41, Gogolya St., Vladivostok, Russia. \\ Natalia Vladimirovna Fedorova, Reshetnev Siberian State University of Science and Technology, 31, Krasnoyarsky Rabochy Av., \\ Krasnoyarsk, Russia. \\ Siberian Federal University, 79, Svobodny Avenue, Krasnoyarsk, Russia. \\ Evgeniia Genadievna Korepanova, Reshetnev Siberian State University of Science and Technology, 31, Krasnoyarsky Rabochy \\ Av., Krasnoyarsk, Russia.
}

\begin{abstract}
This study aims to assess the influence of factors on hotel services consumers behaviour during the stages of the decision-making process. The approach of assessment applied in the study is comprehensive and based on the author's model of consumer behaviour in hotels, which reflects the influence of factors and results indicators for each decision-making stage, which allows for more integrated assessment of the influence of factors on the consumer behaviour in hotels. Surveys on Chinese clients (potential and actual) in hotels, operating in Vladivostok city, Russian Federation, were conducted to empirically test the developed approach of assessment. The results of statistical analysis and its interpretation formed a resource base for developing marketing activities to influence consumer behavior in hotels. The study results make a certain contribution to the development of consumers behaviour studies in hotels and form interest for hoteliers to positively affect their consumers' behavior. Also, providing a clear understanding of the strength, direction and nature of the influence of factors at each stage of the decision-making process will allow the hotel company to correctly distribute limited financial and human resources when planning their marketing activities.
\end{abstract}

Keywords--- Hotel Services, Hotels Consumer Behaviour Model, Influential Factors Assessment Methods, Methodical Approach.

\section{Introduction}

Due to the intense competition and globalizationin today's business environment, the hotel business has become more irrational and requiresadditional efforts to remain competitive and profitable(Liu, Zhang, 2014; Xiang et al., 2015). The competition in the Russian hotel industry has increased due to the continuous growth of accommodation facilities in the country.During the period 2014-2018 the number of accommodation facilities has increased by 94.4\% and reached 20.8 thousand facilities, and respectively, in this period the market volume in the country grew by $29.7 \%$ and reached 129.6 million overnight stays. The growth in hotel sectors was due to the transfer of demand to a lower price segment, and the weakening of the Russian ruble, which ledmany Russian tourists to replace outbound traveling with travel around the country (BusinesStat, 2019).

It should be noted that the hotel sector is more vulnerable to crises than other sectors of any country's economy (Kubickova at al., 2019). In Russia, the average spending on hotel services over the past 5 years has decreased by $16.7 \%$ andreached 4416.2 rubles per stay in 2018.The decrease in average spending was due to the decrease in population real income, the increase in the popularity of economical accommodation facilitiesand the decrease in average stay length in hotels (BusinesStat, 2019).

The consumers' behaviour in hotels business is evolving continuously, leading to more needs and desires $(\mathrm{Xu}$, Li, 2016; Mayorova et al., 2019), which justify the need to conduct marketing research to track those evolving and changes. In the field of hotels consumersbehaviour, contemporary theories and studies did not pay enough attention to the hotel consumers' decision-making stages as a whole process and to the factors, and interrelationship among these factors, that influencing the consumers behaviour during the different stages of decision-making process. In fact, most of the studies was aiming on studying the influence of single factor or group of factors on consumer behaviour in a single stage of decision-making process. 
Knowing the internal and external factors, the direction and strength of their influence on consumer behavior is an undoubted competitive advantage that allows the hotel business to successfully confront various crisis phenomena and to remain competitive in the market (Kubickova at al., 2019). This study provides various tools, to assess the influence of various factors on consumer behavior in hotels which will come handy to hotel operators to keep abreast with the expanding consumers' needs, allowing them to provide a unique hotel experience, distinguishing them from other operators and facing the increasing competition in hotel market.

The purpose of the study is to develop a methodical approach to assess the factors influencinghotel services consumer behavior for the subsequent management of relations with consumers.

The study of consumer behaviour went through different levels and been discussed from different points of view, based on the prevailing scientific trends in each period of time. Table 1 presents the analyze results of various consumer behaviour models, which examines how the factors influencing consumer behaviourhad evolved.

Table 1: The Evaluationof Influential Factors in Consumer Behavior Models

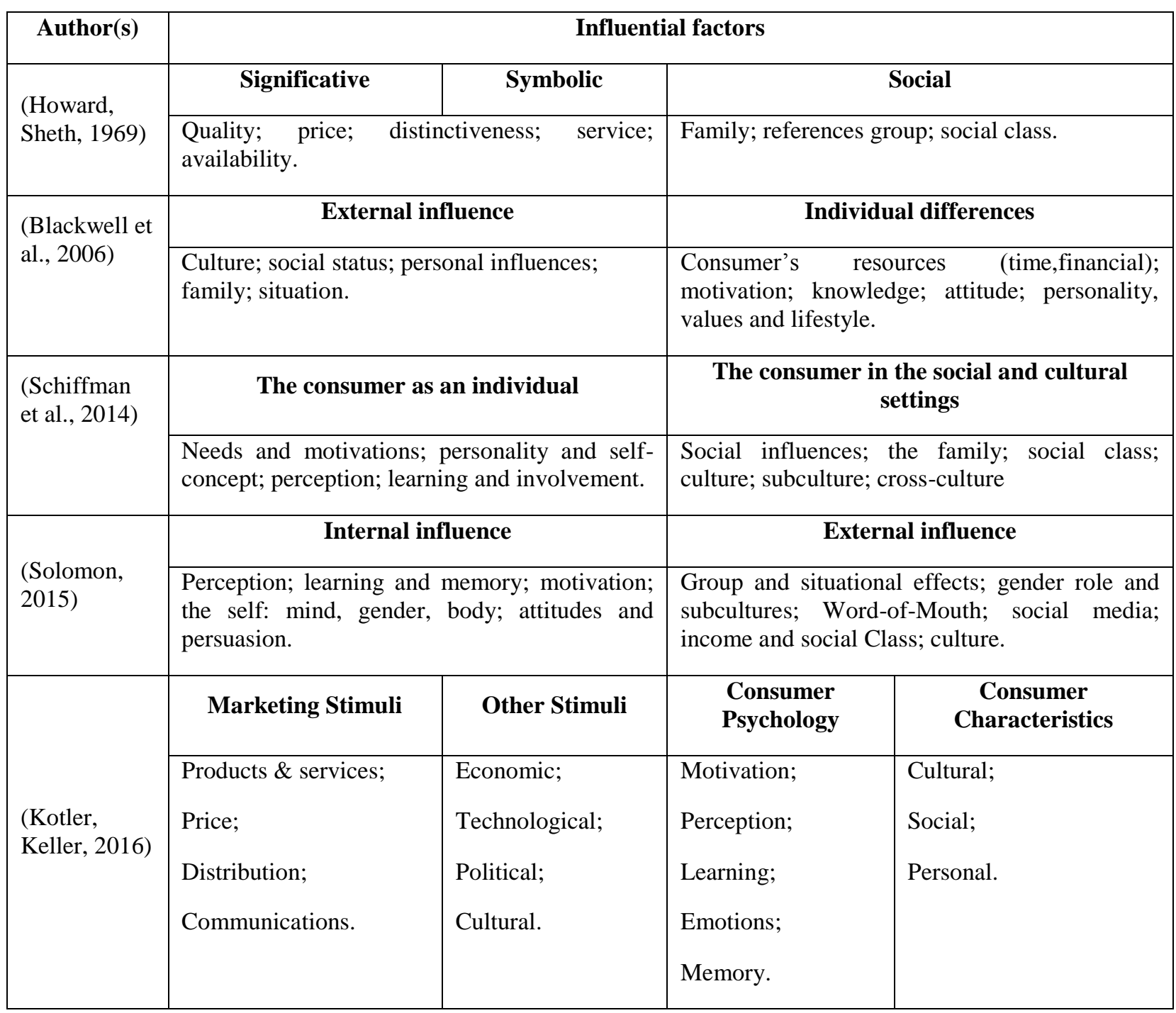

The analyze of various consumer behavior models, in addition to a literature review of more than 80 studies in the field of consumer behavior in hotels, allowed to develop a classification of the factors influencing the hotel services consumers behaviorduring decision-making stages as shown in table 2 . 
Table 2: Factors Influencing the Hotel Services Consumers Behavior During the Stages of Decision-making Process

\begin{tabular}{|c|c|}
\hline \multicolumn{2}{|r|}{ Decision-making stages } \\
\hline \multicolumn{2}{|r|}{ Information search stage } \\
\hline External factors & $\begin{array}{l}\text { Website Features: design; ease of use; perceived usefulness; functionality; security and privacy; } \\
\text { integrity; variety of products; site brand; effort; trust and electronic loyalty. } \\
\text { Information: reliability; quality and quantity. }\end{array}$ \\
\hline Hotel factors & Discounts provided. \\
\hline Internal factors & Previous experience; effect of family, friends and reference groups. \\
\hline \multicolumn{2}{|r|}{ Alternative evaluation stage } \\
\hline External factors & $\begin{array}{l}\text { Technological factors: level of technology. } \\
\text { Political factors: political situation. } \\
\text { Information factors: hotel reviews: valency; framing; rating; reviews quantity; reviewer experience; } \\
\text { hotel response. Social networks, reviews sites and hotel website; site popularity. }\end{array}$ \\
\hline Hotel factors & $\begin{array}{l}\text { Marketing mix: price level: perceived price and value; promotion and advertising; distribution: online } \\
\text { booking; discounts; loyalty program: value (financial, emotional); hotel brand: popularity, quality; } \\
\text { hotel image; hotel reputation. } \\
\text { Hotel location: proximity; convenience of location; availability. Design (exterior and interior) of the } \\
\text { hotel. Hotel classification (number of stars). }\end{array}$ \\
\hline Internal factors & $\begin{array}{l}\text { Social: perceived social pressure; effect and recommendation of family, friends and reference groups; } \\
\text { role and social class; culture and subculture. } \\
\text { Personal: demographic factors: age and life cycle, gender, occupation, economic conditions, } \\
\text { education; personality, self-esteem; preliminary opinions; loyalty; previous experience; habits; brand } \\
\text { preference; similarity between the consumer and the hotel. }\end{array}$ \\
\hline \multicolumn{2}{|r|}{ Consumption stage } \\
\hline External factors & Technological factors: level of technology. Political factors: political stability and regime. \\
\hline Hotel factors & $\begin{array}{l}\text { Value for money: room, food and beverage. Price level. Perceived quality. } \\
\text { Hotel location: proximity; ease of access; convenience. } \\
\text { Hotel Design: external and internal visual appeal. Level of technology. The quality of the physical } \\
\text { environment. Comfortable atmosphere. Image and brand popularity. Hotel Classification. Security } \\
\text { procedures (fire alarm, security staff). Hotel size (number of rooms). } \\
\text { Room - Physical conditions: Size (living room, bathroom, bed), design, amenities, welcome extras } \\
\text { (chocolate, drinks), non-smoking rooms. Room - sensual experience: lighting, soundproofing, comfort } \\
\text { (beds / mattress / pillows); Cleanliness (rooms / beds / bathrooms), smell, temperature, repairs, } \\
\text { atmosphere, quality of sleep. } \\
\text { Food and beverage: variety and quality, portion sizes, food time, atmosphere, special food menu. }\end{array}$ \\
\hline $\begin{array}{l}\text { Hotel factors } \\
\text { (interaction) }\end{array}$ & $\begin{array}{l}\text { Hotel guests (G2G: guest vs. guest): family (with kids); smoking issues; conflicts with other guests. } \\
\text { Hotel guests'behavior and attitude (respect; noise). The similarity of hotel guests (socio-economic). } \\
\text { Hotel staff (S2G: staff vs. guests): professionalism; patience; education; friendly; respect; languages } \\
\text { and communication skills; quick response; check in/out; uniform and cleanliness. Cleaning service. }\end{array}$ \\
\hline Internal factors & $\begin{array}{l}\text { Social: Subjective norm: perceived social risk; family effect. Emotional and cognitive value } \\
\text { (emotions, perceived value and price). } \\
\text { Personal: demographic factors; involvement. }\end{array}$ \\
\hline \multicolumn{2}{|r|}{ Outcomes evaluation stage } \\
\hline External factors & $\begin{array}{l}\text { Information factors: web sites: ease of use; design.Previous reviews: valency; framing; rating, } \\
\text { reviewer experience. } \\
\text { Political factors: political stability and regime. }\end{array}$ \\
\hline Hotel factors & Hotel brand: bias (famous hotel). Quality of food and service; atmosphere; price equity. \\
\hline $\begin{array}{l}\text { Hotel factors } \\
\text { (interaction) }\end{array}$ & Hotel guests: negative behavior; smoking issues; external noises; conflicts. \\
\hline Internal factors & $\begin{array}{l}\text { Social: Subjective norm: influence of opinion of reference groups, family and friends. } \\
\text { Personal: demographic factors; loyalty: switching intention; motivation: extraversion, voluntarily, } \\
\text { altruism, dissonance decrease, helping hotel, helping and empowering other consumers, economic } \\
\text { incentives; dissatisfaction; anger; regret. }\end{array}$ \\
\hline
\end{tabular}

The proposed classificationin table 2 , in addition to consumers behaviour models analysis, served as the basis for constructing the author's model of hotel services consumers behaviour presents in figure 1 . 
In the study, the author adopted the traditional five-step classification for decision-making process, i.e. the cognitive decision sequence of need awareness, information search, alternatives evaluation, purchase and consumption and outcome evaluation(Cox, 1983). The classification in terms of various stages of consumer decision-making is typical of the rational approach to consumer decision-making (Erasmus, 2001). However,need awareness stage for hotel consumers, i.e. the need to book a hotel room, acts as a secondary need arising and existing due to a prior need (Kotler, Keller, 2016). For example, when the need of a person to relax on vacation and travel raises, first he will choose the destination where he will spend his vacation, and only then will choose the hotel inside this destination. Or the need of an employee traveling on a business trip to book a hotel room near his place of work or meeting. Summarizing the previous, it can be noticed that the need to book a hotel room is a secondary need, therefore, it will be isolated from the study.

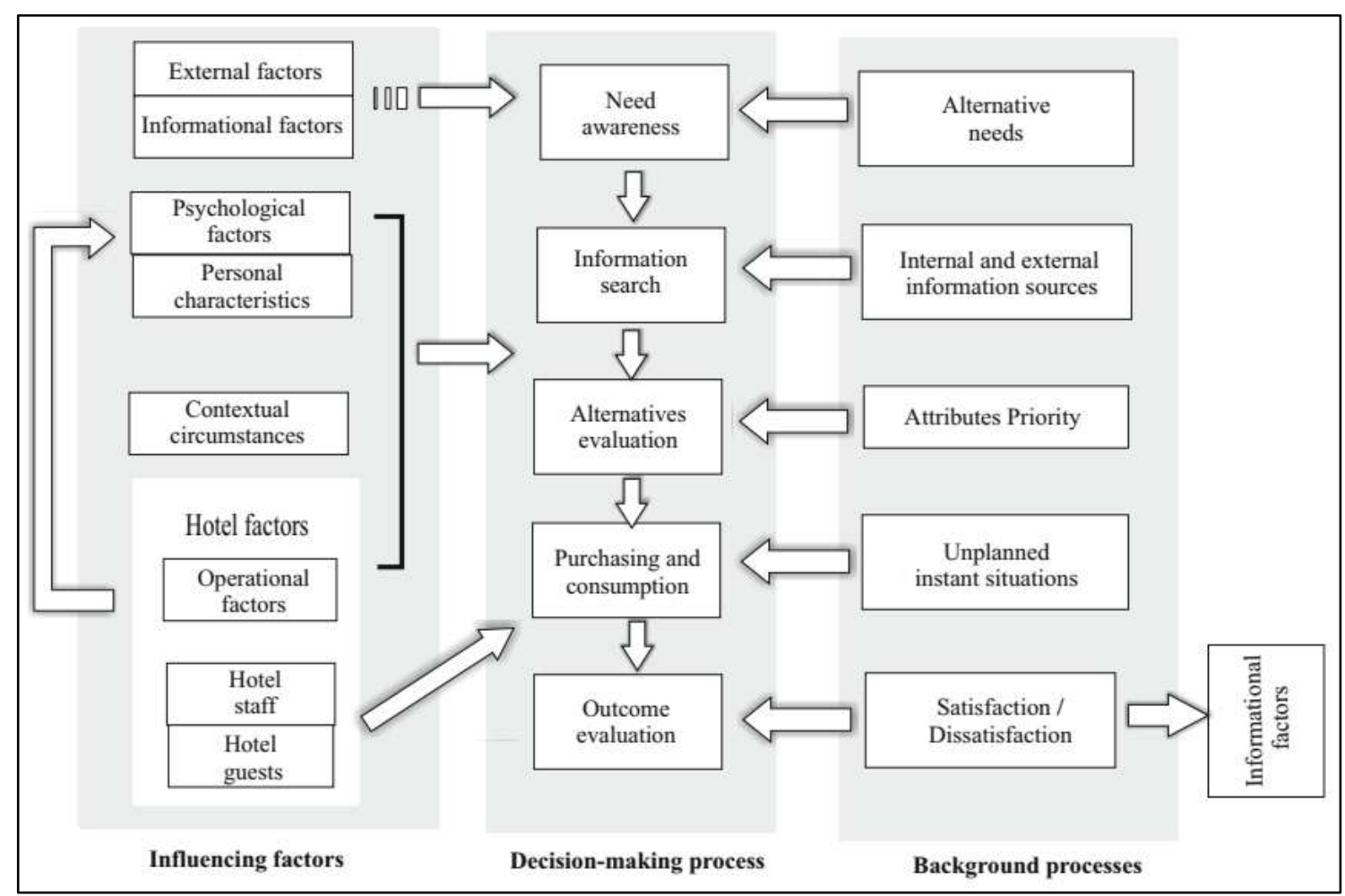

Figure 1: Proposed Model of Hotel Services Consumers Behaviour, During the Stages of Decision-making Process

Moreover, four results indicators alongside various comparative analysis parameters were highlightedin order to assess the actual influence of various factors on consumer behaviourduring the stages of decision-making process as following:1) information search stage: information source use intention (using three information source: social media; booking websites; hotel website) -a derivative of the Technology Acceptance Model (TAM), which is an adaptation of the Theory of Reasoned Action (TRA), which is measured by the intention and the influence of attitude and various factors on the intention to use (Lim et al., 2016); 2) alternatives evaluation stage: purchase intention (two hotel types: economy and luxury hotels) - a derivative of the Theory of Planned Behavior (TPB), which assumes that purchase intention is an indicator of to what extent people are willing to demonstrate certain behavior (Lim et al., 2016) and a salient predictor of actual purchase behavior (Li et al., 2017; Mauri, Minazzi, 2013). 3) purchase stage: satisfaction (two hotel types: economy and luxury hotels) - an evaluation based on a comparison between customers' experiences and their initial expectations (Xu X, Li Y. 2016).4) outcome evaluation stage: motivation to spread WOM (word-of-mouth)- post-consumption behaviour is conditioned by emotions, rather than just cognitive aspects, that mediate between level of satisfaction and consumer post-consumption behavior (Sánchez-García, Currás-Pérez, 2011; Geetha et al., 2017). 


\section{Methods}

The methodical approach to the assessment the influence of factors on hotel services consumers behaviourduring the decision-making process includes: the description of research directions; the formulation of research and discussion questions identified through the literature reviewof the research topic; identifying research problems; formulation research hypothesis, andtheir confirmation or rejectionthrough the empirical testing; designingthe research program; description of the research process and tools; building the assessment model of the influence of factors on consumer behaviour in hotels.

The research covers the following areas of researches in the field of assessment the influence of factors on consumer behaviour in hotels:

- The description of the development and elements of the main of consumer behavior models, by the following authors: Nicosia, F.M., Howard, J.A., Sheth, J.N., Newman, B.L., Gross, B.L., Blackwell, R., Miniard, P., Engel, J.., Kotler, P., Keller, K.L.

- Factors affecting consumer behaviour during the stages of the decision-making process, reflecting the features of hotel services, as following:

1. Information search stage: Chung, N., Koo, C., Liu, J., Zhang, E. Y., Bayer, R-C., Ke, C., Ayeh, J., Au, N., Law, R., and others.

2. Alternatives evaluation stage: Ye, Q., Law, R., Gu, B., Sparks, B., Browning, V., Xie, K.L., Zhang, Z., Kim, D., Perdue, R. R., Tsao, W., Hsieh, M., Shih, L., Lin, T., Li, L., and others.

3. Consumption stage: Liu, Y., Teichert, T., Rossi, M., Li, H., Hu, F., Radojević, T., Albayrak, T., Caber, M., Xiang, Z., Schwartz, Z., Lahap, J. and others.

4. Outcome evaluationstage: Sun, K.A., Kim, D.Y., Casaló, L., Li, C., Cui, G., Peng, L., Banerjee, S., Chua, A., Zhang, Y., Vásquez, C., and others.

- analysis of methodical approaches to the assessment the influence of factors on consumer behavior, in the works of the following authors: Gomilevskaya, G.A., Radojević,et al., Ye,et al., Xiang,et al, Liu, et al, Albayrak, T., Caber, M., Banerjee, S., Chua, A., and others.

Based on the literature review in the field of consumer behaviour in hotels, the following research questions were identified:

- What determines the features of hotel services consumers behavior?

- What approaches, methods and tools exist for the study ofassessment the influence of factors on consumers behaviour?

- How the process ofassessment the influence of factors on consumers behaviourcan be used to create a competitive advantage in the hotel business?

Research questions identified the following discussion questions:

- What are the elements of the hotel services consumer behavior model?

- What does the decision-making process in hotel services include, and what are the factors that have the strongest influence on consumer behaviour in eachstage ofdecision-making process?

- What are the existing methodical approaches to theassessment the influence of factors on consumers behaviourand applicable for hotel services?

Discussion questions allowed to identify the following research problems:

- Consumer behavior theories do not give a clear answer aboutthe elements of consumer behaviour model in hotels and the interaction between these elements, as a result of the absence of consumer behavior model that takes into account the features of hotel services.

- Based on the existing various approaches, methods and toolsin the field of assessment the influence of factors on consumers behaviour, there is no single approach to theassessment the influence of factors on consumers behaviour in hotels in the context of the stages of decision-making process.

The described research problems and literature review contributed in developing the following research hypotheses:

H1: Booking websites, at present time, have become an important source for information search and collection for booking a hotel.

H2: The information published on booking websites and social networks, in the form of reviews or comments, greatly affects the consumer's purchase intentions, and therefore the decision-making process when choosing a hotel. 
H3: There are various factors, allocated beyondthe hotel control, that might affect the consumer behaviour in the consumption stage, and consequently affect the level of guest satisfaction about the hotel.

H4: Factorsinfluencing the consumer behavior inhotels, the nature of this influence (direction, strength) are different for different consumers' segments.

The research process of assessment the influence of factors on hotel services consumers behaviour, presented in figure 2, and itincludes three main stages, and each stage includes various steps, as the following:

\section{- Stage 1. The formation of a set of factors influencing hotels consumer behavior.}

At the first stage, in order to identify the full description of influential factors, a literature review in the field of consumer behaviour models and consumer behaviour in hotels sector was carried out. The result of this analysis is the classification of factors affecting hotels consumer behavior at each stages of the decision-making process (table 2). However, these factors may differ in their effect, based on the characteristics of the consumers, their condition and personality, the purpose of the trip and booking, and others. Thus, these factors will differ in their degree of influence.Further research is needed to verify and justify the influence of these factors on the consumer behavior in hotels and at the same time reduce their number.

Stage 1 . The formation of a set of factors influencing hotels consumer behavior

-Step 1.1 Analysis of the content of consumer behavior models.

-Step 1.2 Literature review of hotels consumer behavior studies.

Stage 2. Justification the influence of factors on hotels consumer behavior during the stages of decision-making process

-Step 2.1 Experts' survey: justify and rank the influence of all factors on hotels consumer behavior during the second and third stage of the decision-making process.

- Step 2.2 Text analytics of consumers reviews on booking websites: justify and rank the influence of all factors on hotels consumers' behavior during the fourth and fifth stages of the decision-making process.

Stage 3. Assessment of factors influencing hotels consumers behavior during the decisionmaking process

- Step 3.1 Conducting consumers surveys to asses the influence of selected (justified) factors on hotels consumers behavior during the decision-making process.

- Step 3.2 Building the assessment model of the influence of factors on consumer behaviour in hotels.

-Step 3.3 Testing and interpretation of the assessment model of the influence of factors on consumer behaviour in hotels..

Figure 2: The Process of Assessment the Influence of Factors on Hotel Services Consumers Behaviour

- Stage2.Justification the influence of factors on hotels consumers behavior during the stages of decision-making process.

The purpose of this stage is to justify and rank the importance of the influence of all factors on consumer behavior. This stage is dividedin two steps:

Step 2.1 Experts' survey.

This step includes the conduction of an experts' survey to measure the influence of various factors on hotels consumers' behavior, at the information search and alternatives evaluation stages of decision-making process, using the results indicators of the two stages (information source use intention, and purchase intention). 


\section{Step 2.2 Reviews text analytics on booking sites}

This step aims to analyze hotels consumers' reviews on booking and travel sites (e.g. Booking.com, TripAdvisor, Expedia, etc.). The purpose of this step is to analyze the reviews of previous guests of different hotels in order to identify factors and measure their influence on the hotel services consumers behavior at the stages: consumption and outcome evaluation (results indicators: consumers' satisfaction and spreading WOM motivation). Similar researches conducted by various authors using qualitative (Zhang, Vásquez, 2014; Xu, Li, 2016; Banerjee, Chua, 2016; Liu et al., 2017) and mixed tools and techniques (Xiang et al., 2015; Ye et al.,2011; Rhee, Yang, 2015; Geetha et al., 2017). The advantage of using guests' reviews is that they reflect actual guests' experiences in hotels. Analyzing guests' reviews allows to determine the factors and attributes most frequently mentioned by the consumers, and thereby examines the influential factors on their satisfaction with the hotel experience (Xiang et al., 2015; Liu et al., 2017; Radojević et al., 2015).

To analyze the guests' reviews, the study followed a text analytics process presented in figure 3, which typically involves several steps including data pre-processing, domain identification, and statistical association analysis (Xiang et al., 2015; Fan et al., 2006). Text analytics refers to the process of extracting useful, meaningful and significant information from unstructured text to overcome information overload (Netzer, 2012). While statistical analysis aims to examine the associations between the identified domain-related words and the dependent variable (i.e., hotel guest satisfaction in this case), the data pre-processing and domain identification, are critical for establishing content validity with the focus on extracting conceptually relevant linguistic entities (Xiang et al., 2015).

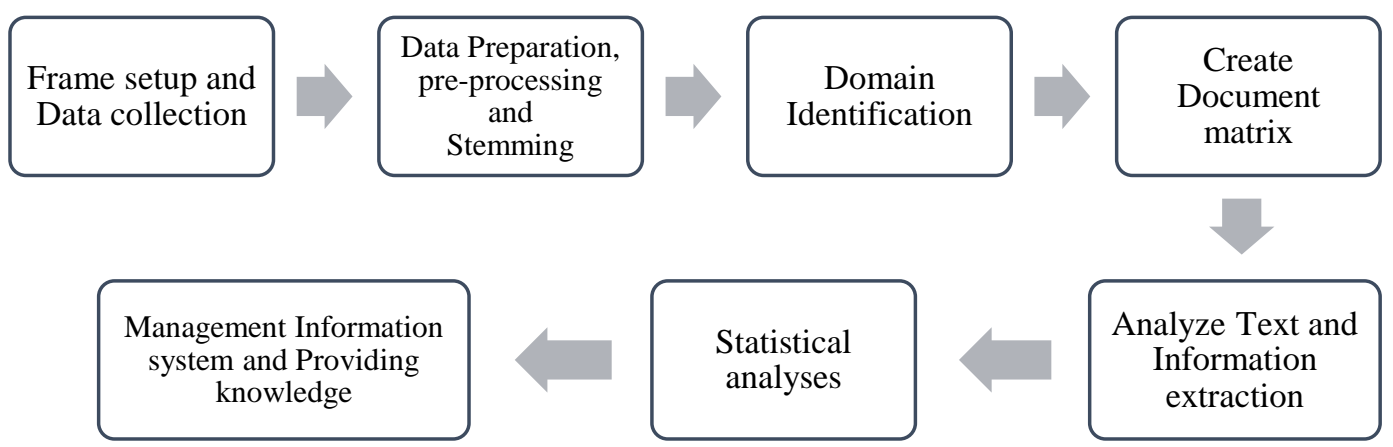

Figure 3: Text Analytics of Consumers' Reviews

At this step, two hypotheses were put forward:

H5: Text analytics of hotels customer reviews allows to identify factors that lead to guests' satisfaction and dissatisfaction in hotels, i.e. the factors affect consumer behavior during and after consumption.

H6: Text analytics of hotels customer reviews allows to create a list of factors affecting the perception of hotel guests during their stay at the hotel.

Thus, theliterature review in stage one allows to form the maximum set of influential factors at each stage of decision-making, and the conduction ofexperts' survey and analyze of consumers' reviews in hotels can reduce the maximum set to the most influential factors in each stage of decision-making process.

- Stage 3. Assessment of factors influencing consumers behavior in hotels during the stages of decision-making process.

The last stage of research process includes the conducting of consumers surveys to assess the influence of the selected factors (in stage two) on the hotel services consumers behavior during each stageof decision-making process. The processing of surveys results using statistical analysis will allow to build the assessment model of the influence of factors on consumer behaviour in hotelsby highlight the most influential factors, and the interpretation of the model will serve as a resource base for developing marketing activities to influence the consumers behavior in hotels. 
The empirical part of the study is devoted to study the Chinese consumers behavior of hotels operating in Vladivostok, Russia. Vladivostok is a developing tourist city, a political, cultural, scientific, educational, economic and administrative center of Russian Far East.

\section{Research Results}

As it was mentioned earlier an experts' survey and consumer reviews analyze will be conducted in order to determine the most influencing factors using factors in table 2.

\section{Experts' Survey}

At this step, an experts' survey was conducted, with a purpose of determining the influence of individual factors on the hotel services consumers behavior. The experts' selection general criteria were their competence in the field of hotel reservation. The experts selected for the survey were 26 hotel clients who had booked and stayed in hotels more than 5 times and at least 3 times in the previous year. The survey was conducted with the help of a Chinese travel agency «Lanbanghai International Travel Agency». The value of experts' level of competencecan vary from 0 (absolute incompetence) to 1 (full competence). The experts' survey was conducted in two parts, to assess the importance of individual factors on hotel services consumers behavior, on the stage of information search and alternatives evaluation. According to the estimates obtained, the competence of experts as a whole is high, and the opinions of experts are consistent. The average level of experts' competence 0.65 , and the concordance coefficient, which allowsto assess the consistency of expert opinions, ranged from 0.52 (information search stage) to 0.67 (alternatives evaluation stage).

To assess the experts' survey results, an average weighting indicator for each expert was calculated for each influential factor. Then the factors influencing consumer behavior were ranked by level of weight.

According to experts, the following factors have the greatest influence on consumer behavior at the information search stage: availability of reviews of other consumers about hotels on the website (74\%); security of personal data and the availability of information about a secure online payment system (73\%); level of integrity and reliability of website information (73\%); availability of discounts, promotions and special offers on the platform (69\%).

Moreover, the following factors have the greatest influence on consumer behavior at the alternatives evaluation stage: reviews framing (the order of positive and negative reviews) (75\%); hotel price (the hotel price level vs. the price level of other hotels in the city) (72\%); previous experience $(70 \%)$; perceived price and value $(68 \%)$; hotel location (including: proximity to the city center and tourist attractions, access to the highway, airport and transport) $(68 \%)$.

Thus, the results of the experts' survey showed the important factors influencing the hotel services consumers behavior at information search and alternatives evaluationstages andallowed to confirm the following hypotheses:H1 andH2.

\section{Consumer Reviews Text Analytics}

At this step, a text analytics of Vladivostok hotels customer reviews were conducted in order to understand the content of customer reviews and highlight the factors that have the greatest impact on guests' satisfaction and dissatisfaction with hotel services using online customer reviews based upon publicly available data in Booking.com.

Data was collected from December 1 to December 10, 2018. The selection includes hotels operating in Vladivostok, Russia. The sample included stars categorized hotels (Federal List of Tourist Objects, 2019), and nonstar stars categorized hotels. For each hotel, all positive and negative customer reviews, purpose of stay and the associated satisfaction rating were collected. All the reviews published by users from the beginning of 2017 to the end of 2018 were collected (the data were limited to the last two years to reflect the opinion of recent guests). Final sample included 58 hotelswith a total of 8476 customer reviews (12,700 positive and negative reviews), and each hotel on average was represented by 146 customer reviews.

The text analytics of customer reviews, followed the following algorithm: (1) purpose of stay (business, leisure); (2) guests' verbal evaluation of the experience (i.e., phrases containing two, three and four words were studied to interpret the words in their correct context) (for example, "excellent location in the center; staff was polite and helpful; excellent value for money, etc.); and (3) expression possible future actions, such as recommending or intention to revisit the hotel. 
As a result, the final processed reviews included 157 unique words (for positive and negative reviews). The frequencies of these 157 words were calculated for each hotel to create a data matrix. Then, these frequencies with an overall rating for each hotel were combined into one data set and imported into SPSS for statistical association analysis using factor analysis. The factor analysis was conducted for the words in positive and negative reviews as presented in table 3.

Table 3: The Results of Factor Analysis of Words in Positive and Negative Reviews

\begin{tabular}{|c|c|c|c|c|c|c|c|}
\hline \multicolumn{4}{|l|}{ Positive reviews } & \multicolumn{4}{|l|}{ Negative reviews } \\
\hline \multirow{2}{*}{ Variables $(N=11)$} & \multicolumn{3}{|c|}{ Components } & \multirow{2}{*}{ Variables $(N=12)$} & \multicolumn{3}{|c|}{ Components } \\
\hline & F1 & F2 & F3 & & F1 & $\mathrm{F} 2$ & F3 \\
\hline Hybrid & & & & Hybrid & & & \\
\hline Bed & 0.920 & & & Bed & 0.977 & & \\
\hline Cleanliness & 0.915 & & & Room & 0.975 & & \\
\hline Comfort & 0.891 & & & Absence of & 0.954 & & \\
\hline Room & 0.880 & & & Size & 0.947 & & \\
\hline Availability & 0.837 & & & Food & 0.828 & & \\
\hline Staff & 0.825 & & & Window & 0.710 & & \\
\hline Hotel accessibility & & & & External inconvenience & & & \\
\hline Center & & 0.905 & & Soundproofing & & 0.949 & \\
\hline Proximity & & 0.846 & & Noise & & 0.887 & \\
\hline Location & & 0.761 & & Neighbors & & 0.876 & \\
\hline Room views & & & & Bathroom condition & & & \\
\hline View & & & 0.971 & Smell & & & 0.928 \\
\hline Sea & & & 0.971 & Dirty & & & 0.880 \\
\hline & & & & Bathroom & & & 0.928 \\
\hline Eigenvalue & 5.24 & 3.01 & 2.15 & Eigenvalue & 5.32 & 3.21 & 2.78 \\
\hline Variance $(\%)$ & 43.68 & 25.1 & 17.95 & Variance $(\%)$ & 44.37 & 26.82 & 23.16 \\
\hline \multicolumn{4}{|c|}{ KMO=0.769, Sig. 0.000} & \multicolumn{4}{|l|}{$\mathrm{KMO}=0.735$, Sig. 0.000 . } \\
\hline
\end{tabular}

Factor analysis allowed to study the structure of words used by guests to explain and express their opinions about hotel experience and to identify the commonality between the variables, which in this case represented a collection of words in a certain component, since the variance is based on the co-occurrences of these words within the same consumer reviews. Thus, the extracted factorsrepresented the common semantic space, i.e., the contexts in which words occurred (Hair et al., 2009; Kmet, 2019; Xiang et al., 2015; Filinova et al., 2015).

The results of text analytics of customer reviews allowed to confirm the following hypotheses: H3, H5 and H6.

Therefore, based on the results of experts' survey and text analytics of customer reviews, table 4 presents a list of factors that most affect the hotel services consumer behavior, in the context of the decision-making process. Factors in table 4 will be used to conduct consumerssurveys to assess the influence of these factors on hotel services consumers behavior.

Table 4: List of Most Affective Factors on Hotel Services Consumer Behavior, During the Decision-making Stages

\begin{tabular}{|c|c|c|c|}
\hline Stages & \multicolumn{2}{|l|}{ Influential factors } & Results indicators \\
\hline Information search & \multicolumn{2}{|l|}{$\begin{array}{l}\text { Reviews; } \\
\text { Security/safety; } \\
\text { Trust; } \\
\text { Discounts. }\end{array}$} & $\begin{array}{l}\text { Intention to use information sources: } \\
\text { Social media; } \\
\text { Booking websites; } \\
\text { Hotel official website. }\end{array}$ \\
\hline $\begin{array}{l}\text { Alternative } \\
\text { evaluation }\end{array}$ & \multicolumn{2}{|l|}{$\begin{array}{l}\text { Reviews framing; } \\
\text { Price; } \\
\text { Previous experience; } \\
\text { Hotel location; } \\
\text { Perceived value. }\end{array}$} & $\begin{array}{l}\text { Purchase intention: } \\
\text { Economy class hotels; } \\
\text { Luxury hotels. }\end{array}$ \\
\hline Consumption & $\begin{array}{l}\text { Cleanliness (bed and room); } \\
\text { Hotel staff; } \\
\text { Hotel location(accessibility); } \\
\text { Room view; } \\
\text { Comfort (convenience in } \\
\text { room); }\end{array}$ & $\begin{array}{l}\text { Size(bed and room); } \\
\text { Bathroom condition; } \\
\text { External inconvenience (interrelation } \\
\text { among guests); } \\
\text { Food quality. }\end{array}$ & $\begin{array}{l}\text { Satisfaction/ } \\
\text { Dissatisfaction: } \\
\text { Economy class hotels; } \\
\text { Luxury hotels. }\end{array}$ \\
\hline $\begin{array}{l}\text { Outcome } \\
\text { evaluation }\end{array}$ & $\begin{array}{l}\text { Expression of positive } \\
\text { feelings; } \\
\text { Altruism; } \\
\text { Help hotels; } \\
\text { Economic incentives. }\end{array}$ & $\begin{array}{l}\text { Expression of negative feelings; } \\
\text { Altruism; } \\
\text { Reduce dissonance. }\end{array}$ & $\begin{array}{l}\text { Spreading WOM motivation (positive } \\
\text { and negative) }\end{array}$ \\
\hline
\end{tabular}


Assessment of factors influencing the hotel services consumers behavior during the stages of decision-making process.

At this stage two surveys of hotels' Chinese consumers (potential and actual) in Vladivostok were conducted for an empirical verification of the third stage of the methodical approach. The purposes of conducting the surveys were the followings:

I) assessment of factors influencing the information source use intention at information search stage from the following information sources: social networks, booking websites and hotel website;

II) assessment of factors influencing the consumers' purchase intentionat alternative evaluation stagefor two hotels options: economy hotels and luxury hotels;

III) assessment of factors influencing the consumers' satisfactionat consumption stage for two hotels options: economy hotels and luxury hotels;

IV) assessment of factors influencing the consumers' intention to spread WOM at outcome evaluation stage.

The population of Heilongjiang province, China, was considered as the general population of two surveys. The total province population in 2018 was 37,8 million. Both surveys aimed at measuring the influence of factors on the behavior of hotels' Chinese consumers in Vladivostok. However, the first survey involved potential consumers, and the second involved actual consumers of Vladivostok hotels. According to the data (Development of tourism in Primorsky Krai for 2013-2020), the flow of Chinese tourists makes up 56\% of the number of foreign tourists visiting Vladivostok, and the total number of foreign tourists visiting the Vladivostok in 2018 amounted to 651.8 thousand people. Also, the creation of the "Primorye" gambling integrated entertainment zone leaded to an increase of inbound tourism flow into Primorye (Martyshenko, 2018).

The size of both samples was 384 of potential and actual respondents respectively.Both samples were calculated with a confidence level of $95 \%$ and $5 \%$ error.

To develop the surveys questions, factors were selected based on the results of experts' survey and consumer reviews text analytics. All factorswere measured by 3-item scalesdeveloped by the following authors: 1) information search stage: "reviews" and "security" (Liu, Zhang, 2014); "trust" (Chung, Koo, 2015); "discounts" (Bayer, Ke, 2013); "source use intention" (Agag, El-Masry, 2016). 2) alternatives evaluation stage: "reviews framing" (Liu, Zhang, 2014); "price" (Jeong, Jang, 2011); "previous experience" (Sánchez-García, Currás-Pérez, 2011); "hotel location"(Rhee, Yang, 2015);"perceived value"and "purchase intention"(Chiang, Jang, 2007). 3) consumption stage:"cleanliness", "size" and bathroom condition" (Gu, Ryan, 2008); "hotel staff" and "external inconvenience" (Walls, 2013); "room view" (Kim, Perdue, 2013); "comfort" (Mohsin, Lengler, 2015); "food quality" (Ismail et al. 2016). 4) outcome evaluation stage: "release positive feelings" and "helping the hotel" (Jeong, Jang, 2011); "altruism", "economic incentives" and"dissonance reduction" (Yen, Tang, 2015); "release negative feelings" and "spreading WOM motivation” (Sánchez-García, Currás-Pérez, 2011).

All questions then were translated in Chinese language. Respondents were asked to rate their agreement with statements on a seven-point scale (Likert scale).

Surveys results wereanalyzedusing ordinal regression analysis to assess the influence of factors on consumer behaviour.Moreover, the results correlation analysis showed a statistically insignificant relationship between the independent variables at each stage.

\section{Results of first survey}

The first survey conducted betweenMayandJuly 2019 using an online survey instrument, a total of 415 answers were collected, and, 384 answers were accepted for analysis. This survey targeted the potential hotels consumers with the purpose of assessment the influence of factors on their behaviour during three stages of decision-making process, namely: information search, alternatives evaluation and outcome evaluation stages.

\subsection{Assessment of Factors Influencing the Information Source Use Intention at Information Search Stage}

At this stage the information source use intention(social networks, booking websites and the hotel website) was used as a dependent variable.The following factors were used as independent variables: reviews (quantity and quality of reviews provided by sites); security (personal information of the client); trust (in information sources); and discounts (offered by sites).

The responders were asked to evaluate the factors affecting their intention to use the three sources of information. Table 5 presents the assessments results of factors influencing information source use intention, for each individual information source. 
Table 5: Results of Ordinal Regression Analysis at Information Search Stage

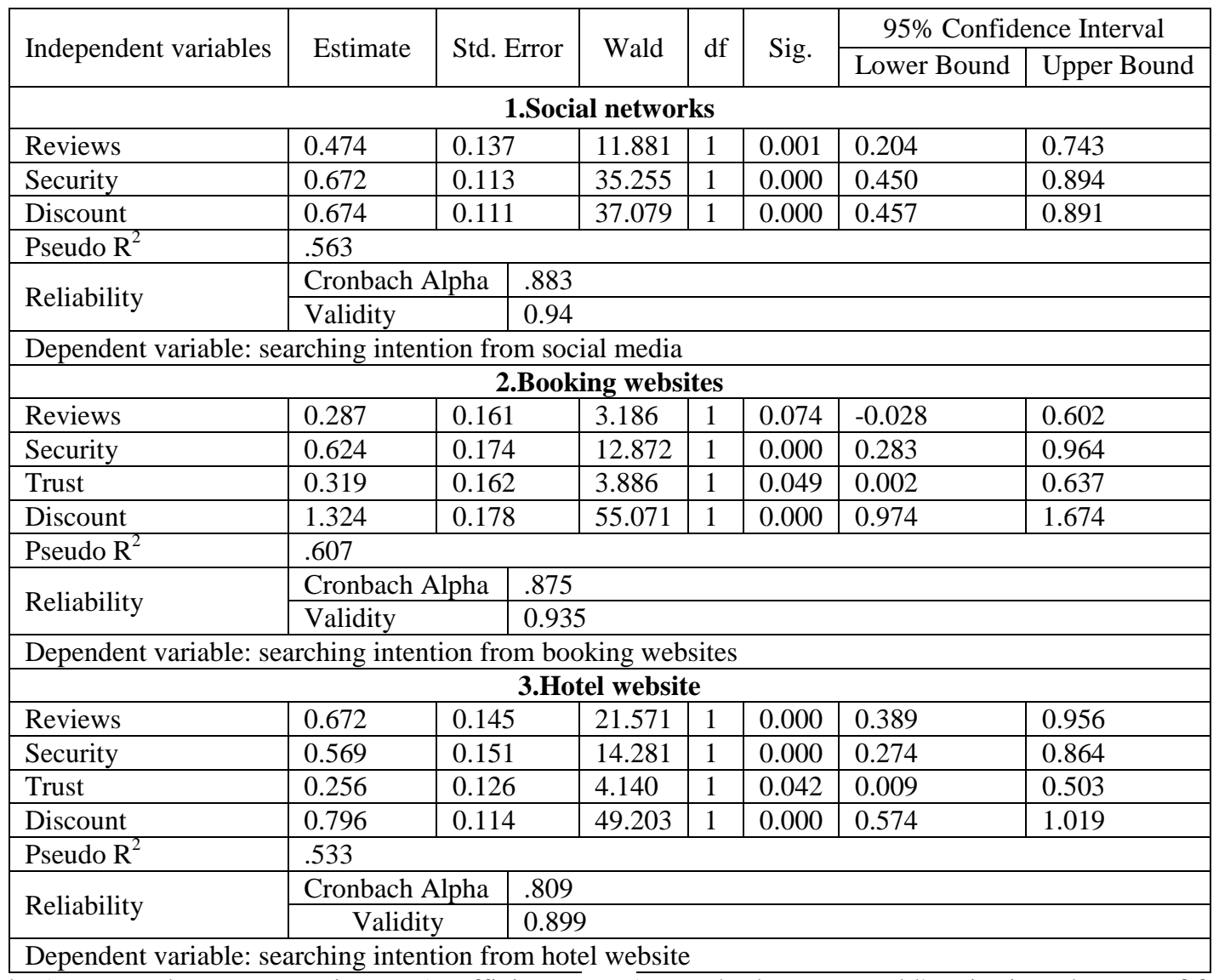

Table 5 presentedparameter estimates (coefficients-Beta), standard errors, Wald's criterion, degrees of freedom, associated values of statistical significance and $95 \%$ confidence interval of coefficients, pseudo $\mathrm{R}^{2}$ and test reliability statistics.

First, for social networks with a confidence interval of $95 \%$, the variables "reviews", "security" and "discount" were statistically significant, while "trust" was not. The coefficient value of independent variable refers to its influence on the dependent variable.The interpretationof results $-\operatorname{Exp}([$ Beta] $)$ value: when $X$ changes by one unit (that is, from 1 to 2), the probability that $Y$ go to another level (from 1 to 2 or from 2 to 1 ) is equal to $\exp ([\mathrm{Beta}]$ ) which is associated with X. E.g. for the factor"reviews", when its value increase by one unit (i.e., from 1 to 2), the probability that the dependent variable will move to a higher level increasesby the $\exp (0.474)$, given all other variables in the model remain constant.The value of the pseudo $\mathrm{R}^{2}$ indicates that $56.3 \%$ of the variation of the dependent variable is explained by the proposed model (this is a relatively small value, but expected result, because the dependent variable is influenced by numerous factors). Thus, the variable "discount" has the strongest influence on the intention to use social networks, followed by "security" and "reviews".

Second, for booking websites with a confidence interval of 95\%, the variables "trust", "security", "discount" and "reviews" (90\%) were statistically significant, and the value of pseudo $\mathrm{R}^{2}$ was $60.7 \%$. Thus, on the intention to use booking websites"discount"has the strongest influence, followed by "Security", "trust" and "reviews" respectively.

Third, for hotel website with a confidence interval of 95\%, all independent variables were statistically significant, and the value of pseudo $\mathrm{R}^{2}$ was $53.3 \%$. Thus, on the intention to use hotel website "discount" has the strongest influence, followed by "reviews", "Security" and "trust" respectively.

\subsection{Assessment of Factors Influencing the Consumers' Purchase Intention at Alternatives Evaluation Stage}

At this stage the purchase intention (for economy and luxury hotels) was used as a dependent variable. The following factors were used as independent variables: reviews framing; price (hotel level price); previous experience (in booking); hotel location; andperceived value. 
The responders at this stage, were asked to evaluate the factors affecting their purchase intention from two hotel types. Table 6 presents the assessments results of factors influencing consumers' purchase intention for two hotel types.

Table 6: Results of Ordinal Regression Analysis at Alternative Evaluation Stage

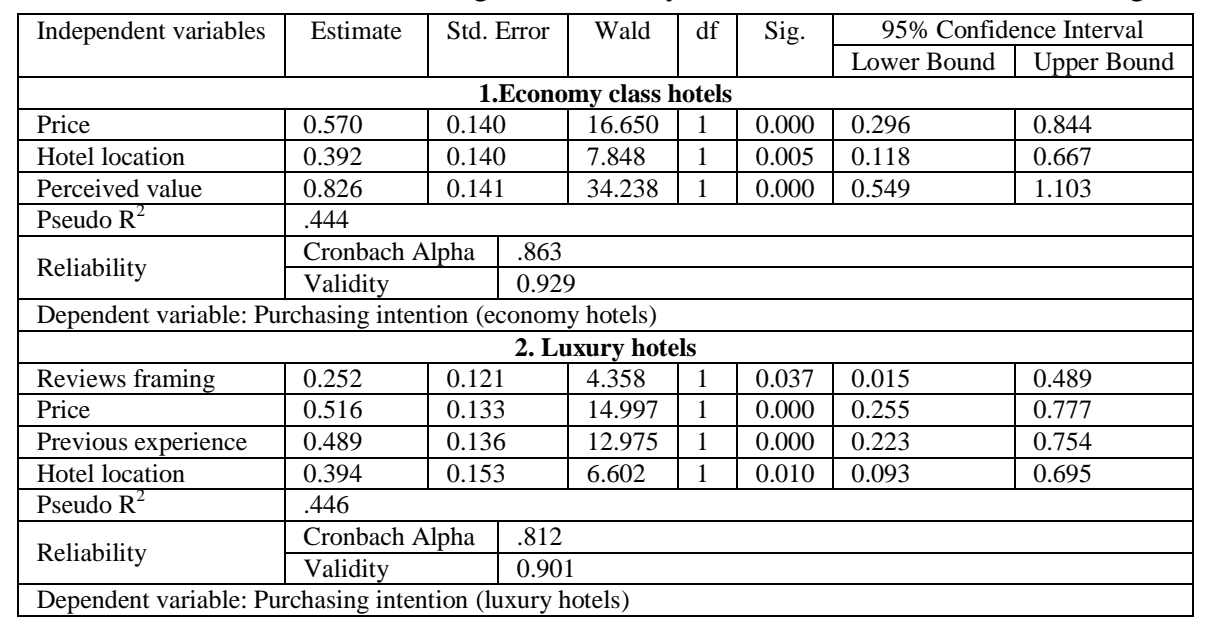

First, for economy class hotels with a confidence interval of 95\%, the following variables were statistically significant: "price", "hotel location" and "perceived value", and the value of pseudo $\mathrm{R}^{2}$ was $44.4 \%$. Thus, on consumers' purchase intention from economy class hotel "perceived value" has the strongest influence, followed by "price"and "hotel location" respectively.

Second, for luxury class hotels with a confidence interval of $95 \%$, the variables: "reviews framing", "Price", "previous experience" and "hotel location" were statistically significant, and the value of pseudo $\mathrm{R}^{2}$ was $44.6 \%$. Thus, on consumers' purchase intention from luxury class hotel "price" has the strongest influence, followed by "previous experience","hotel location" and "reviews framing" respectively.

\subsection{Assessment of Factors Influencing the Consumers' Motivation to Spread WOM at Outcome Evaluation Stage}

This stage wasdivided in two parts: first, the motivation to spread positive WOM was used as a dependent variable and the following factors were used as independent variables: expression of positive feelings, altruism, helping the hotel and economic incentives; second, the motivation to spread negative WOM was used as a dependent variable and the following factors were used as independent variables: expression of negative feelings, altruism and reduce dissonance.

The responders at this stage, were asked to evaluate the factors affecting their motivation to spread WOM about the hotel. Table 7 presents the assessments results of factors influencing consumers' motivation to spread positive/negative WOM.

Table 7: Results of Ordinal Regression Analysis at Outcome Evaluation Stage

\begin{tabular}{|c|c|c|c|c|c|c|c|c|}
\hline \multirow[t]{2}{*}{ Independent variables } & \multirow[t]{2}{*}{ Estimate } & \multirow{2}{*}{\multicolumn{2}{|c|}{ Std. Error }} & \multirow[t]{2}{*}{ Wald } & \multirow[t]{2}{*}{ df } & \multirow[t]{2}{*}{ Sig. } & \multicolumn{2}{|c|}{$95 \%$ Confidence Interval } \\
\hline & & & & & & & Lower Bound & Upper Bound \\
\hline \multicolumn{9}{|c|}{ 1.Positive WOM } \\
\hline Expression of positive feelings & 0.551 & 0.135 & & 16.798 & 1 & 0.000 & 0.288 & 0.815 \\
\hline Altruism & 0.905 & 0.164 & & 30.527 & 1 & 0.000 & 0.584 & 1.227 \\
\hline Helping hotels & 0.619 & 0.142 & & 18.950 & 1 & 0.000 & 0.340 & 0.897 \\
\hline Economic incentives & -0.314 & 0.078 & & 16.387 & 1 & 0.000 & -0.467 & -0.162 \\
\hline Pseudo $\mathrm{R}^{2}$ & \multicolumn{8}{|c|}{.47} \\
\hline \multirow{2}{*}{ Reliability } & \multicolumn{2}{|c|}{ Cronbach Alpha } & \multicolumn{6}{|c|}{.600} \\
\hline & \multicolumn{4}{|c|}{\begin{tabular}{l|l} 
Validity & 0.774 \\
\end{tabular}} & & & & \\
\hline \multicolumn{9}{|c|}{ Dependent variable: Motivation to spread positive WOM } \\
\hline \multicolumn{9}{|c|}{ 2. Negative WOM } \\
\hline Expression of negative feelings & 0.452 & \multicolumn{2}{|c|}{0.131} & 11.865 & 1 & 0.001 & 0.195 & 0.709 \\
\hline Altruism & 0.976 & \multicolumn{2}{|c|}{0.137} & 50.894 & 1 & 0.000 & 0.708 & 1.244 \\
\hline Reduce dissonance & 0.360 & \multicolumn{2}{|c|}{0.137} & 6.938 & 1 & 0.008 & 0.092 & 0.627 \\
\hline Pseudo $\mathrm{R}^{2}$ & \multicolumn{8}{|c|}{.465} \\
\hline \multirow{2}{*}{ Reliability } & \multicolumn{2}{|c|}{ Cronbach Alpha } & \multicolumn{6}{|c|}{.799} \\
\hline & \multicolumn{2}{|c|}{ Validity } & \multicolumn{6}{|c|}{0.894} \\
\hline
\end{tabular}


First, for the motivations to spread positive WOM with a confidence interval of $95 \%$, all variables were statistically significant, and the value of pseudo $\mathrm{R}^{2}$ was $60 \%$. Thus, on consumers' motivations to spread positive WOM the following factors have the strongest influence in order, "altruism", "helping hotel", "expression of positive feelings" and "economic incentives".

Second, for the motivations to spread negative WOM with a confidence interval of $95 \%$, also all variables were statistically significant, and the value of pseudo $\mathrm{R}^{2}$ was $46.5 \%$. Thus, on consumers' motivations to spread negative WOM the following factors have the strongest influence in order, "altruism", "expression of positive feelings" and "reduce dissonance".

\section{Results of Second Survey}

The second survey conducted between July and October 2019 using an online survey instrument, a total of 402 and 397 answers were collected for economic and luxury hotels respectively, as a result, 384 answers for each hotels type were accepted for analysis. The respondents of this survey were actual consumers of hotels and had experience living in hotels in Vladivostok.This survey conducted with the purpose of assessment the influence of factors on consumers'behaviour during consumption stage of decision-making process.

In this survey the consumers' satisfaction indicator was selected as a dependent variable in two hotel options: luxury hotels (stars categorized) and economy class hotels (non-stars categorized). The following factors were used as independent variables: cleanliness (rooms and beds); hotel staff; hotel location;room view; comfort; size (rooms and beds); bathroom condition; external inconvenience; quality of food (offered by luxury hotels).

The responders at this stage, were asked to evaluate the factors affected their satisfaction during their stay in the hotels. Table 8 presents the assessments results of factors influencing consumers' satisfaction at consumption stag.

Table 8: Results of Ordinal Regression Analysis at Consumption Stage

\begin{tabular}{|c|c|c|c|c|c|c|c|c|}
\hline \multirow{2}{*}{ Independent variables } & \multirow{2}{*}{ Estimate } & \multirow{2}{*}{\multicolumn{2}{|c|}{ Std. Error }} & \multirow{2}{*}{ Wald } & \multirow[t]{2}{*}{$\mathrm{df}$} & \multirow[t]{2}{*}{ Sig. } & \multicolumn{2}{|c|}{ 95\% Confidence Interval } \\
\hline & & & & & & & Lower Bound & Upper Bound \\
\hline \multicolumn{9}{|c|}{ 1. Luxury hotels } \\
\hline Cleanliness & 0.616 & \multicolumn{2}{|c|}{0.284} & 4.709 & 1 & 0.030 & 0.060 & 1.172 \\
\hline Hotel staff & 0.460 & \multicolumn{2}{|c|}{0.247} & 3.470 & 1 & 0.062 & -0.024 & 0.944 \\
\hline Room view & 1.316 & \multicolumn{2}{|c|}{0.314} & 17.580 & 1 & 0.000 & 0.701 & 1.931 \\
\hline Size & -0.946 & \multicolumn{2}{|c|}{0.288} & 10.810 & 1 & 0.001 & -1.509 & -0.382 \\
\hline Pseudo $\mathrm{R}^{2}$ & \multicolumn{8}{|l|}{.553} \\
\hline \multirow{2}{*}{ Reliability } & \multicolumn{4}{|c|}{\begin{tabular}{l|l} 
Cronbach Alpha & .856 \\
\end{tabular}} & & & & \\
\hline & \multicolumn{4}{|c|}{\begin{tabular}{l|l} 
Validity & 0.925 \\
\end{tabular}} & & & & \\
\hline \multicolumn{9}{|c|}{ Dependent variable: guest satisfaction in luxury hotels } \\
\hline \multicolumn{9}{|c|}{ 2. Economy class hotels } \\
\hline Cleanliness & 0.502 & \multicolumn{2}{|c|}{0.254} & 3.910 & 1 & 0.048 & 0.004 & 1.000 \\
\hline Hotel staff & 1.066 & \multicolumn{2}{|c|}{0.329} & 10.501 & 1 & 0.001 & 0.421 & 1.710 \\
\hline Hotel location & 0.443 & \multicolumn{2}{|c|}{0.224} & 3.912 & 1 & 0.048 & 0.004 & 0.883 \\
\hline Bathroom condition & -0.766 & \multicolumn{2}{|c|}{0.282} & 7.361 & 1 & 0.007 & -1.319 & -0.213 \\
\hline External inconvenience & -0.529 & \multicolumn{2}{|c|}{0.213} & 6.192 & 1 & 0.013 & 0.112 & 0.945 \\
\hline Pseudo $\mathrm{R}^{2}$ & \multicolumn{8}{|c|}{.495} \\
\hline \multirow{2}{*}{ Reliability } & \multirow{2}{*}{\multicolumn{2}{|c|}{$\begin{array}{l}\text { Cronbach Alpha } \\
\text { Validity }\end{array}$}} & \multicolumn{6}{|c|}{.88} \\
\hline & & & \multicolumn{6}{|c|}{0.938} \\
\hline
\end{tabular}

First, for luxury hotels with a confidence interval of $95 \%$, the following variables were statistically significant: "cleanliness", "hotel staff" (90\%), "room view" and "size", and the value of pseudo $\mathrm{R}^{2}$ was $55.3 \%$. Thus, on consumers' satisfaction in luxury hotel "room view" has the strongest positive influence, followed by "cleanliness" and "hotel staff" respectively, while "size" has negative influence on consumers" satisfaction.

Second, for economy hotels with a confidence interval of $95 \%$, the following variables were statistically significant: "cleanliness", "hotel staff", "hotel location", "bathroom condition" and "external inconvenience", and the value of pseudo $\mathrm{R}^{2}$ was $49.5 \%$. Thus, the factors "hotel staff", "cleanliness" and "hotel location" have the 
strongest influence consumers' satisfaction in economy hotelsrespectively, while "bathroom condition" and "external inconvenience" have negative effect on it.

Moreover, the surveys results allowed to compare the influence of factors on two groupsof hotel consumers, namely, business and leisure consumers, which confirmed the hypotheses $\mathrm{H} 4$.

Table 9 presents the mathematical models for calculating the probability of odds ratio "Logit (P [Y])" after eliminating insignificant factors in each stage of decision-making process.

Table 9: Mathematical Models of the Influence of Factors on the Hotel Services Consumers Behavior in Vladivostok

\begin{tabular}{|c|c|c|}
\hline $\begin{array}{l}\text { Decision-making } \\
\text { stages }\end{array}$ & Mathematical models (assessments models) & Variables description \\
\hline \multirow[t]{3}{*}{$\begin{array}{l}\text { Information search } \\
\text { stage }\end{array}$} & $\operatorname{Logit}\left(\mathrm{p}\left[\mathrm{y}_{1}\right]\right)=0.474 \mathrm{x}_{11}+0.672 \mathrm{x}_{12}+0.674 \mathrm{x}_{14}$ & $\begin{array}{l}\mathrm{Y}_{1} \text { - searching intention from } \\
\text { social media; } \\
\mathrm{X}_{11}, \mathrm{X}_{21}, \mathrm{X}_{31} \text {-reviews; } \\
\mathrm{X}_{12}, \mathrm{X}_{22}, \mathrm{X}_{32} \text {-security; } \\
\mathrm{X}_{23}, \mathrm{X}_{33}-\text { trust; } \\
\mathrm{X}_{14}, \mathrm{X}_{24}, \mathrm{X}_{34} \text { - discounts. }\end{array}$ \\
\hline & $\operatorname{logit}\left(\mathrm{p}\left[\mathrm{y}_{2}\right]\right)=0.287 \mathrm{x}_{21}+0.624 \mathrm{x}_{22}+0.319 \mathrm{x}_{23}+1.324 \mathrm{x}_{24}$ & $\begin{array}{l}\mathrm{Y}_{2}-\text { searching intention from } \\
\text { booking websites. }\end{array}$ \\
\hline & $\operatorname{logit}\left(\mathrm{p}\left[\mathrm{y}_{3}\right]\right)=0.672 \mathrm{x}_{31}+0.569 \mathrm{x}_{32}+0.256 \mathrm{x}_{33}+0.796 \mathrm{x}_{34}$ & $\begin{array}{l}\mathrm{Y}_{3}-\text { searching intention from } \\
\text { hotel website. }\end{array}$ \\
\hline \multirow[t]{2}{*}{$\begin{array}{l}\text { Alternatives } \\
\text { evaluation stage }\end{array}$} & $\operatorname{logit}\left(\mathrm{p}\left[\mathrm{y}_{4}\right]\right)=0.57 \mathrm{x}_{42}+0.392 \mathrm{x}_{44}+0.794 \mathrm{x}_{45}$ & $\begin{array}{l}\mathrm{Y}_{4} \text {-purchasing intention } \\
\text { (economy class hotels); } \\
\mathrm{X}_{42}, \mathrm{X}_{52}-\text { hotel price level; } \\
\mathrm{X}_{44}, \mathrm{X}_{54}-\text { hotel location; } \\
\mathrm{X}_{45}-\text { perceived value. }\end{array}$ \\
\hline & $\operatorname{logit}\left(\mathrm{p}\left[\mathrm{y}_{5}\right]\right)=0.252 \mathrm{x}_{51}+0.516 \mathrm{x}_{52}+0.489 \mathrm{x}_{53}+0.394 \mathrm{x}_{54}$ & $\begin{array}{l}\mathrm{Y}_{5}-\text { purchasing intention (luxury } \\
\text { hotels); } \\
\mathrm{X}_{51}-\text { reviews framing; } \\
\mathrm{X}_{53} \text {-previous experience. }\end{array}$ \\
\hline \multirow[t]{2}{*}{ Consumption stage } & $\operatorname{logit}\left(\mathrm{p}\left[\mathrm{y}_{6}\right]\right)=0.616 \mathrm{x}_{61}+0.46 \mathrm{x}_{62}+1.316 \mathrm{x}_{64}-0.946 \mathrm{x}_{66}$ & $\begin{array}{l}\mathrm{Y}_{6}-\text { guest satisfaction in luxury } \\
\text { hotels; } \\
\mathrm{X}_{61}, \mathrm{X}_{71}-\text { cleanliness; } \\
\mathrm{X}_{62}, \mathrm{X}_{72}-\text { hotel staff; } \\
\mathrm{X}_{64}-\text { room view; } \\
\mathrm{X}_{66}-\text { size of room and bed. }\end{array}$ \\
\hline & $\begin{array}{l}\operatorname{logit}\left(\mathrm{p}\left[\mathrm{y}_{7}\right]\right)=0.502 \mathrm{x}_{71}+1.066 \mathrm{x}_{72}+0.443 \mathrm{x}_{73^{-}} \\
0.766 \mathrm{x}_{77}+0.529 \mathrm{x}_{78}\end{array}$ & $\begin{array}{l}\mathrm{Y}_{7}-\text { guest satisfaction in economy } \\
\text { class hotels; } \\
\mathrm{X}_{73} \text { - hotel location; } \\
\mathrm{X}_{77} \text { - bathroom condition; } \\
\mathrm{X}_{78} \text { - external inconvenience. }\end{array}$ \\
\hline \multirow[t]{2}{*}{$\begin{array}{l}\text { Outcome evaluation } \\
\text { stage }\end{array}$} & $\operatorname{logit}\left(\mathrm{p}\left[\mathrm{y}_{8}\right]\right)=0.551 \mathrm{x}_{81}+0.905 \mathrm{x}_{82}+0.619 \mathrm{x}_{83}-0.314 \mathrm{x}_{84}$ & $\begin{array}{l}\mathrm{Y}_{8}-\text { motivation to spread positive } \\
\text { WOM; } \\
\mathrm{X}_{81}-\text { expression of positive } \\
\text { feelings; } \\
\mathrm{X}_{82}-\text { altruism; } \\
\mathrm{X}_{83}-\text { helping hotel; } \\
\mathrm{X}_{84}-\text { economic incentives. }\end{array}$ \\
\hline & $\operatorname{logit}\left(\mathrm{p}\left[\mathrm{y}_{9}\right]\right)=0.452 \mathrm{x}_{91}+0.976 \mathrm{x}_{92}+0.36 \mathrm{x}_{93}$ & $\begin{array}{l}Y_{9}-\text { motivation to spread negative } \\
\text { WOM; } \\
\mathrm{X}_{91}-\text { expression of negative } \\
\text { feelings; } \\
\mathrm{X}_{92}-\text { altruism; } \\
\mathrm{X}_{93} \text { - reduce dissonance. }\end{array}$ \\
\hline
\end{tabular}


The probability of odds ratio "Logit (P $[\mathrm{Y}])$ " for each dependent variable at each level of the scale can be calculated as in formula (1).

where:

$$
\operatorname{logit}[p(y \leq j)]=a_{j}-\sum[\text { Beta }]_{i} X_{i}
$$

$\mathrm{j}=1,2,3 \ldots, \mathrm{J}$-scale of the dependent variable; (7-point scale, from 1 to 7 , where 1 strongly disagrees and 7 strongly agree);

$\mathrm{i}=1,2,3, \ldots, \mathrm{I}-$-number of independent variables.

Thus, analyzing the results of consumer surveys using ordinal regression analysis allowed to assess the influence of factors on hotel services consumers behavior in the context of individual stages of the decision-making process. The assessment process took into account the features of each decision-making stage and included the responses results of potential and actual consumers of hotel services in Vladivostok, covering various aspects of decisionmaking process.

\section{The Discussion of the Results}

The results of testing the proposed methodical approach (on the example of Vladivostok hotels) allowed to assess the factors in each decision-making stage, which quantitatively describe the influence of various factors on the hotel services consumers behavior. The assessment of the influential factorscontributesin developing marketing activities to influence the behavior of hotel services consumers, which allow to correctly distribute the limited hotel resources and efforts to reachanutmost understanding and influence on consumers to achieve maximum benefits and profits from these resources.

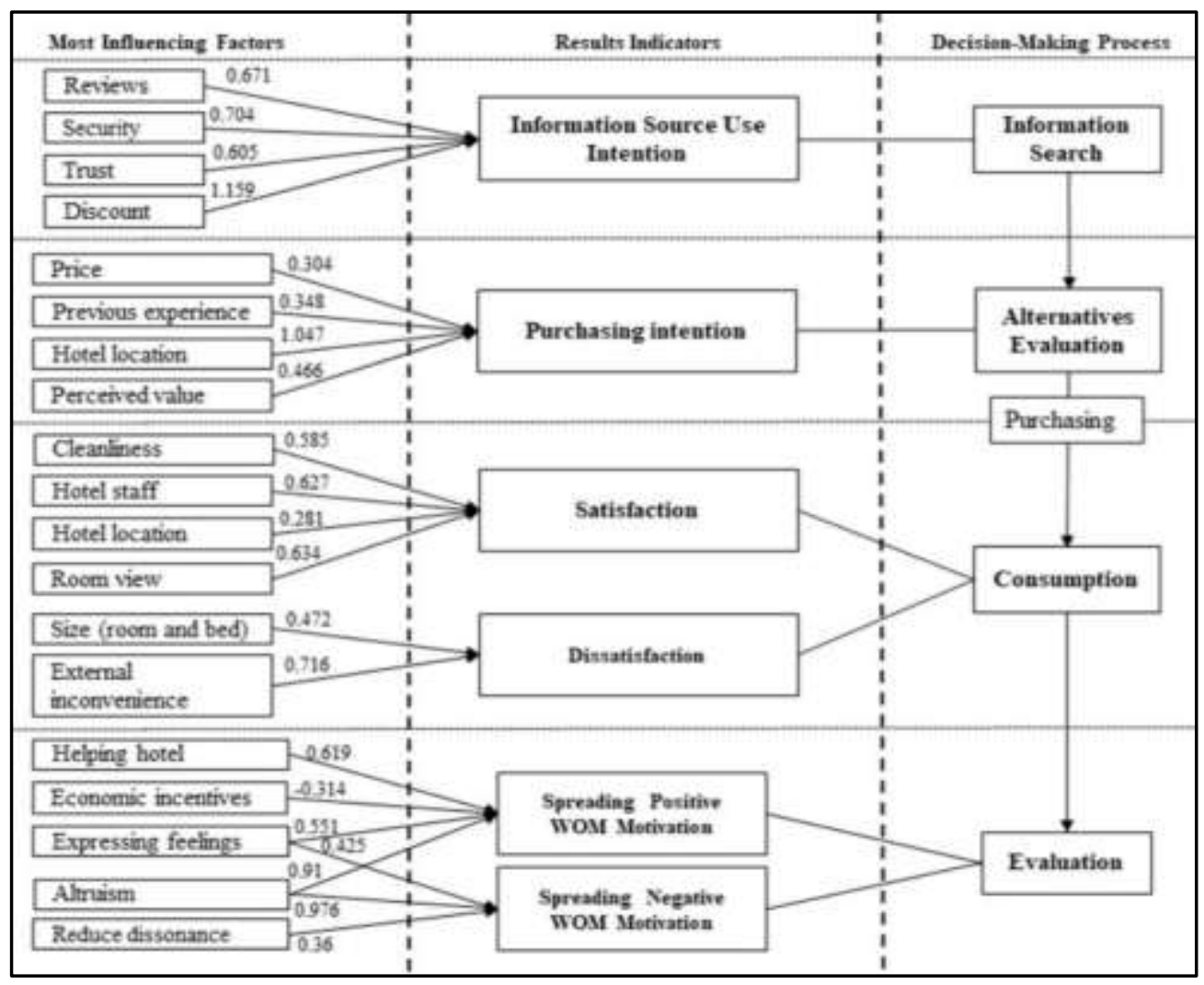

Figure 4: The Assessment Model of the Influence of Factors on Consumer Behaviour in Hotels During the Stages of Decision-Making Process (Vladivostok Hotels)

The use of various empirical research tools (experts' survey, guest reviews text analytics) made it possible to reduce and clarify the most influential factors on the behavior of hotel services consumers. The importance of using the aforementioned tools lies in their ability to clarify the assessment model of actual hotel services consumers behavior in the context of decision-making stages. 
The most influential factors on hotel services consumers behavior in Vladivostok hotels during the decisionmaking stages are presented in Figure 4. In order to build the final model of the influential factors on consumers behavior in each stage of decision-making process in Vladivostok hotels, the surveys answers were combined for each respondent and each factor (for each comparative analysis parameter), then the average value for each question was calculated and an ordinal regression analysis was performed for each stage.

Figure 5 presents a scheme of marketing activities to influence the consumers behavior in Vladivostok hotels based on the assessment model of the influence of factors on consumer behaviour in hotels. The scheme includes recommended actions at each stage of decision-making and the expected results of the application of these actions.

\begin{tabular}{|c|c|c|c|c|c|c|c|c|}
\hline \multirow{2}{*}{ 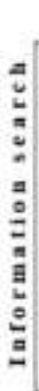 } & \multirow{2}{*}{ 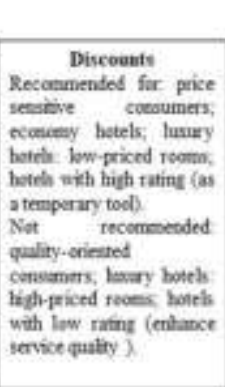 } & \multicolumn{3}{|c|}{ Recoamaneaded actians: } & & & & Expected results \\
\hline & & \multicolumn{2}{|c|}{ 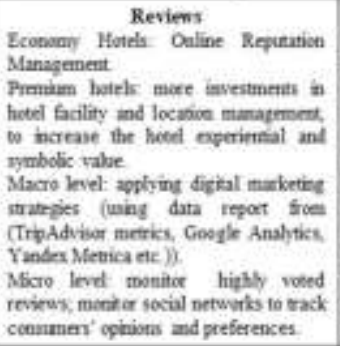 } & \multicolumn{2}{|c|}{ 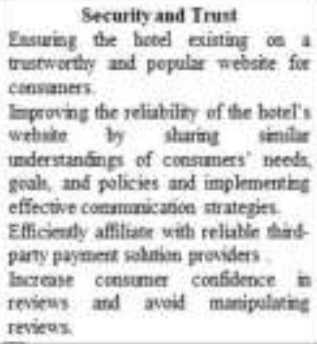 } & \multicolumn{2}{|c|}{ 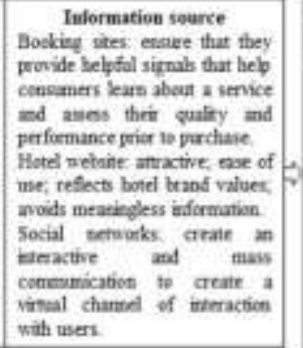 } & Anracting thit potentul castomens amertion \\
\hline & \multicolumn{7}{|c|}{ रा } & \multirow{2}{*}{ 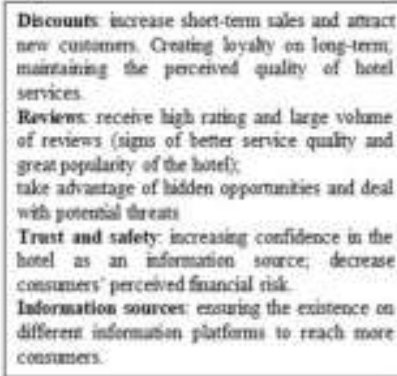 } \\
\hline & \multirow{3}{*}{\multicolumn{2}{|c|}{ 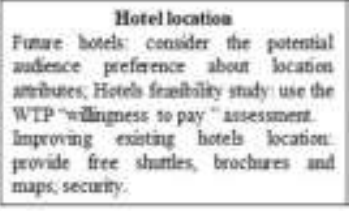 }} & \multirow{3}{*}{\multicolumn{2}{|c|}{ 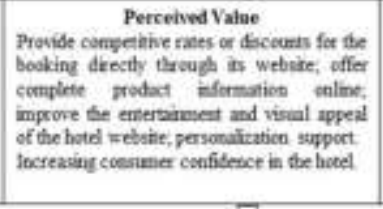 }} & \multirow{3}{*}{\multicolumn{2}{|c|}{ 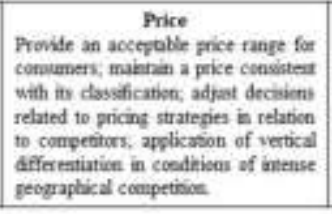 }} & \multirow{3}{*}{ 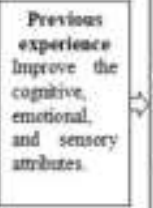 } & \\
\hline & & & & & & & & 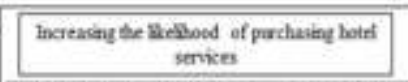 \\
\hline & & & & & & & & \\
\hline & \multicolumn{7}{|c|}{ ए3 } & carrent buted. \\
\hline & \multirow{2}{*}{\multicolumn{5}{|c|}{ 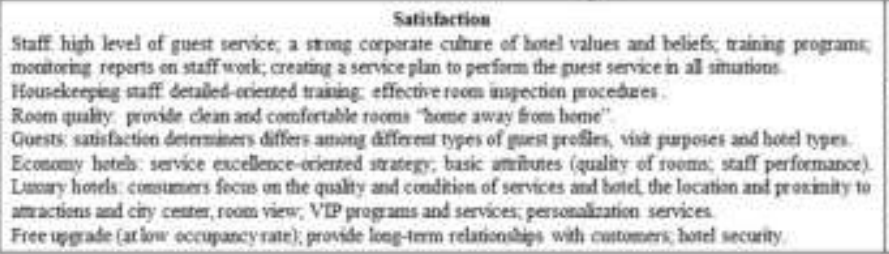 }} & \multirow{2}{*}{\multicolumn{2}{|c|}{ 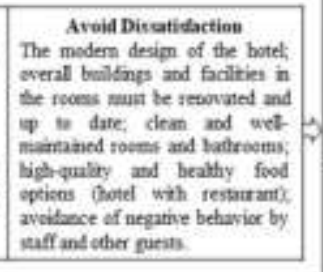 }} & 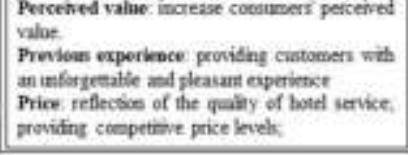 \\
\hline & & & & & & & & 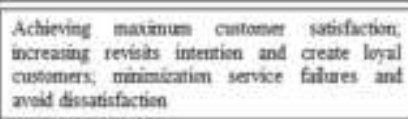 \\
\hline
\end{tabular}

Figure 5: The Formation of Marketing Activities Scheme to Influence the Hotel Services Consumers Behavior in Vladivostok City

Thus, given that marketing budgets are limited, an understanding of the influencing factors allows hotel operators to effectively manage their resources. Therefore, it is recommended to adhere a holistic, integrated and strategic approach in the development of marketing activities in order to maximize and effectively influence consumers in the decision-making process. However, with limited resources and budgets, hotels may not be able to spend additional resources to influence the behavior of guests. Thus, the determining of importance of factors affecting consumer behavior, as shown in the study, can be used to form a priority list of hotel activities.

\section{Conclusion}

At present time, the increasingly competition pace in hotel business, and the increasing consumer power, arising from their ability to examine and compare different hotel options through various information sources, justify the relevance of studying consumer behavior in hotels and the factors affecting their behavior in the decision-making process. Thus, the study of consumer behavior and influential factors helps managers to understand the needs and desires of consumers and the most important factors affecting their behavior at each stage of this process, which allow the hotel management to concentrate its limited resources on these factors.

The main contribution of this work is the theoretical justification and empirical verification of the methodical approach to the assessment the factors influencing consumer behavior in hotels during the decision-making stages (using various comparative analysis parameters), which allowed a more integrated assessment of the impact of factors on consumer behavior in hotels. A distinctive feature of the approach is a comparative analysis of the 
influence of factors on the results indicators of each decision-making stage in the context of comparative analysis parameters (information channels, hotel types and WOM polarity).

It should be noted that the presented research results may have prospects for further developments in the direction of assessing factors affecting the behavior of different consumer groups in hotels in order to develop strategies for promoting hotel services to attract them.

In a nutshell, the main objective of the hotel is to satisfy the consumer at each stage of the decision-making process. Proper understanding of the factors, allow the hotel to influence the behavior of its guests, transforming: an interested consumer into a potential one (information search stage), a potential consumer into an actual customer/buyer (alternative comparison stage), an actual customer into a satisfied guest (consumption stage), satisfied guest into a loyal one (outcome evaluation stage). And even a dissatisfied guest through feedback and reputation management activities can be persuaded to return to the hotel again.

\section{References}

[1] Agag, G. and A.A. El-Masry, 2014. Understanding the determinants of hotel booking intentions and moderating role of habit. International Journal of Hospitality Management. 54(3): 52-67.

[2] Banerjee, S. and A.Y.K. Chua, 2016. In search of patterns among travellers' hotel ratings in TripAdvisor. Tourism Management. 53(2): 125-131.

[3] Bayer, R.C. and C. Ke, 2013. Discounts and consumer search behavior: The role of framing. Journal of Economic Psychology. 39(6): 215-224.

[4] Blackwell, R.D. Miniard, P.W. Engel, J. F., 2006. Consumer behavior (10-ed.). Aufl., Mason, pp: 774.

[5] BusinesStat. Analysis of the hotel services market in Russia in 2014-2018, forecast for 2019-2023. Date Views 01.12.2019. www.marketing.rbc.ru/research/27205/.

[6] Chiang, C.F. and S.S. Jang, 2007. The effects of perceived price and brand image on value and purchase intention: Leisure travelers' attitudes toward online hotel booking. Journal of Hospitality \& Leisure Marketing. 15(3): 49-69.

[7] Chung, N. and C. Koo, 2015. The use of social media in travel information search. Telematics and Informatics. 32(2): 215-229.

[8] Cox, A., Granbois, Dh. And J. Summers, 1983. Planning, search, certainty and satisfaction among durables buyers: alongitudinal study. Advances in Consumer Research. 10(1): 394-399.

[9] Erasmus, A.C., Boshoff, E. and G. Rousseau, 2001. Consumer decision-making models within the discipline of consumer science: a critical approach. Journal of Family Ecology and Consumer Sciences. 29(1): 82-90.

[10] Fan, W., Wallace, L., Rich, S. and Z. Zhang, 2006. Tapping the power of text mining. Communications of the ACM. 49(9): 76-82.

[11] Filinova N.V., Bobinkin S.A., Matveeva S.V., Dembitckaia O.U., Akatova N.S. The influence of individual psychological abilities on managerial activities of line managers. Asian Social Science. 2015. T. 11. № 7. C. 208-214.

[12] Geetha, M., Singha, P. and S. Sinha, 2017. Relationship between customer sentiment and online customer ratings for hotels - An empirical analysis. Tourism Management. 61(4): 43-54.

[13] Gu, H. and C. Ryan, 2008. Chinese clientele at Chinese hotels-Preferences and satisfaction. International Journal of Hospitality Management. 27(3): 337-345.

[14] Hair, J.F., Black, W.C., Barry, J., Babin, B.J. and R.E. Anderson. 2009. Multivariate Data Analysis, 7th ed. Upper Saddle River, NJ., pp: 734.

[15] Howard, J.A. Sheth, 1969. The Theory of Buyer Behavior. New York: John Wiley and Sons, pp: 458.

[16] Ismail, T.A.T., Muhammad, R., Yusoff, N.M. and M.S.M. Shariff, 2016. The myth and reality of hotel brand and food quality: the case of hotel restaurants in Malaysia. Procedia-Social and Behavioral Sciences. 222(7): 382-389.

[17] Jeong, E. and S.S. Jang, 2011. Restaurant experiences triggering positive electronic word-of-mouth (eWOM) motivations. International Journal of Hospitality Management. 30(2): 356-366.

[18] Kaur, K. A. W. A. L. J. E. E. T., and N. E. E. N. A. Malhotra. "Telecommunications and economic growth in India: Causality analysis." International Journal of Research in Business Management 2.5 (2014): 31-46.

[19] Kim, D. and R.R. Perdue, 2013. The effects of cognitive, affective, and sensory attributes on hotel choice. International Journal of Hospitality Management. 35(4): 246-257. 
[20] Kmet, E.B., 2019. Multi-Level Image of a Successful University Graduate in the Information Management for the Supply Chain in Education System. International Journal of Supply Chain Management. 8 (6): 866878.

[21] Kotler, P. and K.L. Keller, 2016. Marketing management (15 ed.). Essex. England.: Pearson, pp: 833.

[22] Kubickova, M., Kirimhan, D. and H. Li, 2019. The impact of crises on hotel rooms' demand in developing economies: The case of terrorist attacks of $9 / 11$ and the global financial crisis of 2008. Journal of Hospitality and Tourism Management. 38(1): 27-38.

[23] Kumar, S. A. N. J. E. E. V., and D. E. E. P. A. L. I. Bhatnagar. "Effect of Food and Service Quality on Customer Satisfaction a Study of 3 Star Hotels in Punjab Region." International Journal of Sales \& Marketing Management 7.4 (2017): 35-48.

[24] Li, L., Peng, M., Jiang, N. and R. Law, 2017. An empirical study on the influence of economy hotel website quality on online booking intentions. International Journal of Hospitality Management. 63(4): 1-10.

[25] Lim, Y.J., Osman, A., Salahuddin, S.N., Romle, A.R. and S. Abdullah, 2016. Factors Influencing Online Shopping Behavior: The Mediating Role of Purchase. Procedia Economics and Finance. 35(1): 401-410.

[26] Liu, J. and E.Y. Zhang, 2014. An investigation of factors affecting customer selection of online hotel booking channels. International Journal of Hospitality Management. 39(4): 71-83.

[27] Liu, Y., Teichert, T., Rossi, M., Li, H. and F. Hu, 2017. Big data for big insights: Investigating languagespecific drivers of hotel satisfaction with 412,784 user-generated reviews. Tourism Management. 59(2): 554-56.

[28] Mauri, A.G. and R. Minazzi, 2013. Web reviews influence on expectations and purchasing intentions of hotel potential customers. International Journal of Hospitality Management. 34(3): 99-107.

[29] Martyshenko, N.S., 2018. Tourist industry development prospects in Vladivostok under the launch of "Primorye" integrated entertainment zone. Journal of Environmental Management and Tourism. 2018. 2 (26): 310-317

[30] Mayorova, A., Kevorkova, Z., Sapozhnikova, N., Luneva, E. State and development of retail chains in the Russian regions. Proceedings of the 33rd International Business Information Management Association Conference, IBIMA 2019: Education Excellence and Innovation Management through Vision 2020

[31] Mohsin, A. and J. Lengler, 2015. Service experience through the eyes of budget hotel guests: do factors of importance influence performance dimensions?. Journal of Hospitality and Tourism Management. 23(2): 23-34.

[32] Netzer, O., Feldman, R., Goldenberg, J. and M. Fresko, 2012. Your Own Business: Market-Structure Surveillance Through Text Mining. Marketing Science. 31(3): 521-543.

[33] Radojević, T., Stanišić, N. and N. Stanić, 2015. Ensuring positive feedback: Factors that influence customer satisfaction in the contemporary hospitality industry. Tourism Management. 51(6): 13-21.

[34] RAHMAN, MOHAMMAD TOUFIQUR. "ANALYSIS OF SERVICE ENCOUNTER: CUSTOMER'S VIEWPOINT REGARDING HOTEL SERVICES IN COX'S BAZAR CITY, BANGLADESH."

[35] Report on the implementation and assessment of the effectiveness of the state program of the Primorsky Territory "Development of tourism in Primorsky Krai for 2013-2020, approved by the Decree of the Administration of the Primorsky Territory of December 7, 2012. \# 396-PA" for 2018. Date Views 07.10.2019. www.primorsky.ru/upload/medialibrary/4d6/4d64c25905c47fd967e0a 446b5c5 0732.pdf.

[36] Rhee, H.T. and S-B. Yang, 2015. Does hotel attribute importance differ by hotel? Focusing on hotel starclassifications and customers' overall ratings. Computers in Human Behavior. 50(9): 576-587.

[37] Sánchez-García, I. and R. Currás-Pérez, 2011. Effects of dissatisfaction in tourist services: the role of anger and regret. Tourism Management. 32(1): 1397-1406

[38] Schiffman, L.G, O'Cass, A., Paladino, A. and J. Carlson, 2014. Consumer Behaviour (10-ed.). Australia: Pearson, pp: 672.

[39] Solomon, M.R., 2015. Consumer behaviour: Buying, Having, and Being (11-ed.). New Jersey: Pearson, pp: 607.

[40] Tuzon-Guarin, Joanna Marie. "Housekeeping Management Practices and Standards of Selected Hotels and Restaurants of Ilocos SUR, Philippines." International Journal of Business Management \& Research (IJBMR) ISSN (P) (2016): 2249-6920.

[41] SINGLA, AMIT. "THE EFFECT OF PERCEIVED SERVICE QUALITY ON CUSTOMER SATISFACTION IN INDIAN RAILWAYS."

[42] Walls, A. R., 2013. A cross-sectional examination of hotel consumer experience and relative effects on consumer values. International Journal of Hospitality Management. 32(1): 179-192. 
[43] Xiang, Z., Schwartz, Z., Gerdes Jr. J.H. and M. Uysal, 2015. What can big data and text analytics tell us about hotel guest experience and satisfaction? International Journal of Hospitality Management. 44(1):120130.

[44] Xiao, Yan, and Lina Zhao. "A COMPARATIVE STUDY OF THE CONTRIBUTION OF VALUEADDED SERVICES TO CHINA'S TOTAL INDUSTRY EXPORT."

[45] Xu, X. and Y. Li, 2016. The antecedents of customer satisfaction and dissatisfaction toward various types of hotels: A text mining approach. International Journal of Hospitality Management. 55(4): 57-69.

[46] Ye, Q., Law, R., Gu, B. and W. Chen, 2011. The influence of user-generated content on traveler behavior: An empirical investigation on the effects of e-word-of-mouth to hotel online bookings. Computers in Human Behavior. 27(1): 634-639.

[47] Yen, C.L.A. and C.H.H. Tang, 2015. Hotel attribute performance, eWOM motivations, and media choice. International Journal of Hospitality Management. 46(3): 79-88.

[48] Zhang, Y. and C. Vásquez, 2014. Hotels' responses to online reviews: Managing consumer dissatisfaction. Discourse, Context and Media. 6(4): 54-64. 